\title{
ANALISIS HUBUNGAN KARAKTERISTIK PEMIMPIN TERHADAP PRODUKTIVITAS KERJA PADA PROYEK KONSTRUKSI DI DAERAH ISTIMEWA YOGYAKARTA
}

\author{
Oleh : Indra Suharyanto' \\ E-mail: indrasuharyanto@gmail.com
}

\begin{abstract}
ABSTRAK: Era globalisasi telah menjangkau berbagai sektor kehidupan. Dunia bisnis jasa konstruksi adalah salah satu bagian yang mengalami kemajuan yang pesat. Setiap perusahaan bersaing dalam meningkatkan produktivitasnya. Sumber daya manusia adalah modal utama dalam setiap peningkatan itu. Diantaranya pemimpin yang bergerak di dalamnya. Setiap pemimpin memiliki ciri khas / karakteristik dalam menjalankan perusahaannya. Pemimpinlah yang akan membawa kemana arah bisnis. Penelitian ini adalah penelitian lapangan dengan metode kuantitatif. Dengan sampel pemimpin-pemimpin perusahaan yang tergabung dalam Badan Sertifikasi Asosiasi. Varibel yang diteliti adalah karakteristik pemimpin $(X)$ dan produktivitas kerja (Y) sehingga menghasilkan hubungan antara karakteristik pemimpin terhadap produktivitas kerja pada proyek konstruksi. Nilai karakteristik pemimpin dari hasil seluruh instrumen yang dominan sebesar 59,6\% dan nilai dominan dari produktivitas kerja pada proyek konstruksi di DIY sebesar 45,6\%. Setelah dilakukan pengujian hipotesis dengan menggunakan uji statistik korelasi Pearson Product Moment, diperoleh sig $\rho(0,000)<\alpha(0,01)$, disimpulkan bahwa karakteristik pemimpin sangat berhubungan kuat terhadap produktivitas kerja, dengan tingkat signifikansi 1.
\end{abstract}

Kata-kata Kunci: Karakteristik Pemimpin, Produktivitas Kerja, Proyek Konstruksi.

\section{PENDAHULUAN}

Pembangunan di Indonesia semakin berkembang terutama pada sektor industri jasa konstruksi. Perubahan bukan hanya pada peralatan konstruksi yang serba canggih, namun pada perubahan sosial dan bertambah ketatnya persaingan bisnis dewasa ini. Dalam rangkaian kegiatan pembangunan ada suatu proses yang mengolah sumber daya proyek, diantaranya Sumber Daya Manusia. Proses yang terjadi dalam rangkaian kegiatan itu tentunya melibatkan pihak-pihak yang terkait, baik secara langsung maupun tidak langsung. Pemimpin merupakan seseorang yang mempunyai hubungan dengan para bawahan dalam menjalankan visi dan misinya pada suatu perusahaan terkait guna meningkatkan produktivitas. Setiap pemimpin mempunyai cara, gaya atau karakteristik dalam menjalankan kepemimpinannya / perusahaan.

Keberhasilan suatu proyek dapat diukur dari produktivitasnya, untuk mendapatkan suatu produktivitas yang optimal, selain didukung oleh modal dan peralatan yang canggih juga didukung oleh sumber daya manusia yang baik. Jadi pemimpinlah yang menentukan ke mana arah bisnis.

Penelitian ini dibatasi pada :

a) Perusahaan Jasa Pelaksana Konstruksi di Daerah Istimewa Yogyakarta,

b) Pengukuran produktivitas dilakukan pada faktor manusia,

c) Karakteristik pemimpin yang diteliti adalah karakteristik birokratis dan karakteristik otokratis.

Tujuan penulisan ini adalah untuk menganalisis karakteristik pemimpin dan produktivitas kerja pada proyek konstruksi serta menganalisis hubungan karakteristik pemimpin terhadap produktivitas kerja. Sehingga manfaat dari hasil penelitian ini diharapkan dapat mengembangkan praktik kepemimpinan dalam pelaksanaan pembangunan proyek konstruksi.

1) adalah staf pengajar Program Studi Teknik Sipil Universitas Cokroaminoto Yogyakarta 


\section{TINJAUAN PUSTAKA}

\subsection{Kepemimpinan}

A Dale Timpe (2002), dalam literaturnya mengklasifikasikan pemimpin menjadi enam klasifikasi: otokratis, birokratis, diplomatis, konsultatif, demokratis, kendali bebas. Seorang pemimpin yang efektif harus memperhatikan dengan baik orang maupun produksi. Menciptakan iklim dimana orang dapat bekerjasama untuk mendapatkan hasil yang bermutu.

Pekerjaan pemimpin adalah memobilisasi kekuatan mental dan sosial dari individu agar para bawahan termotivasi untuk bekerja sama, dengan penuh pengertian dan kepercayaan, menuju sasaran bersama yaitu produktivitas. Unsur vital dalam produktivitas yaitu efisiensi dan efektivitas. Produktivitas sangat peka terhadap daya saing, tingkat inflasi dan standar kehidupan masyarakat. Oleh karena itu, pemimpin cenderung akan menjadi pusat perhatian oleh banyak kalangan (oleh para ekonomi, para manajer baik tingkat pemerintah maupun swasta).

\section{A. Teori Pemimpin dan Kepemimpinan}

Ada 3 teori yang menonjol dalam menjelaskan kemunculan pemimpin, yaitu:

1. Teori genetis, yang menyatakan sebagai berikut: Pemimpin itu tidak dibuat, akan tetapi lahir jadi pemimpin oleh bakat-bakat alami yang luar biasa sejak lahirnya. Dia ditakdirkan lahir menjadi pemimpin dalam situasi dan kondisi yang bagaimanapun juga.

2. Teori social, yang menyatakan sebagai berikut: Pemimpin harus disiapkan, dididik dan dibentuk serta tidak dilahirkan begitu saja. Setiap orang bisa jadi pemimpin, melalui usaha penyiapan dan pendidikan, serta didorong oleh kemauan sendiri.

3. Teori ekologis atau sinteris, yang menyatakan sebagai berikut: Seseorang akan sukses menjadi pemimpin, bila sejak lahirnya dia telah memiliki bakat-bakat kepemimpinan dan bakat-bakat ini sempat dikembangkan melalui pengalaman dan usaha pendidikan

Beberapa definisi mengenai kepemimipinan adalah sebagi berikut :

1. Benis mengenai kepemimpinan berkata sebagi berikut: “...the prosess by which an agent induces a subordinate to behave in a destred manner" (proses dengan mana seorang agen menyebabkan bawahan bertingkah laku menurut cara tertentu).

2. Ordeway Tead dalam bukunya The Art Of Leadership menyatakan sebagai berikut: kepemimpinan adalah kegiatan mempengaruhi orang-orang agar mereka mau bekerjasama untuk mencapai tujuan yang diinginkan.

3. George R. Terry dalam bukunya Principle Of Management berkata bahwa kepemimipinan adalah kegiatan memperngaruhi orang-orang agar mereka suka berusaha mencapai tujuan-tujuan kelompok.

4. Howart H. Hoyt Aspek Of Modera Public Administration menyatakan: kepemimpinan adalah seni untuk mempengaruhi tingkah laku manusia, kemampuan untuk membimbing orang.

\section{B. Macam-Macam Karakteristik Pemimpin}

A Dale Timpe, 2002, dalam bukunya mengklasifikasikan gaya / karakteristik pemimpin menjadi 6 karakter diantaranya:

1. Otokratis: mengeluarkan perintah, memberitahu bawahan apa yang harus dikerjakan.

2. Birokratis: mengembangkan dan memberlakukan peraturan untuk mengendalikan semua prilaku dan situasi. 
3. Diplomasi: membujuk dan memotivasi bawahan, menjual gagasan pada mereka agar mendapatkan pesanan.

4. Konsultatif: mengundang gagasan dari, berkonsultasi dengan bawahan sebelum mengambil keputusan akhir.

5. Demokratis: membicarakan keputusan dengan bawahan dengan maksud mencari consensus atau pandangan mayoritas.

6. Kendali Bebas: menetapkan sasaran bagi bawahan, kemudian memberikan kebebasan sebanyak mungkin kepada mereka.

Cara yang digunakan untuk menganalisis berbagai karakter yang dimiliki tiap karakteristik ialah dengan melakukan kategorisasi dari berbagai karakter itu berdasarkan:

1. Persepsi seorang pimpinan tentang peranannya selaku pimpinan,

2. Nilai-nilai yang dianut,

3. Sikap dalam mengemudikan jalannya organisasi,

Gaya kepemimpinan seseorang akan identik dengan karakteristik kepemimpinan orang yang bersangkutan. Artinya, untuk kepentingan pembahasan, istilah karakteristik dan gaya dapat dipandang sebagai sinonim.

\subsection{Produktivitas}

Dalam doktrin pada konfrensi Oslo, 1984, tercantum definisi umum produktivitas semesta, yaitu :

"Produktivitas adalah suatu konsep yang bersifat universal yang bertujuan untuk menyediakan lebih banyak barang dan jasa untuk lebih banyak manusia, dengan menggunakan sumber-sumber riil yang makin sedikit."

Produktivitas adalah suatu pendekatan interdisipliner untuk menentukan tujuan yang efektif, pembuatan rencana, aplikasi penggunaan cara yang produktiv untuk menggunakan sumber daya-sumber daya secara efesien, dan tetap menjaga adanya kualitas yang tinggi.

\section{A. Produktivitas Dalam Perusahaan / Organisasi}

Perubahan-perubahan pada lingkungan organisasi / perusahaan tidak akan pernah surut dan bahkan selalu muncul dalam berbagai keragaman. Proses adaptasi terhadap bentuk-bentuk perubahan itu dengan sendirinya tidak bisa dihindari dan malahan terus ditingkatkan.

Tindakan perbaikan bisa berupa restrukturisasi untuk mencapai rasionalisasi teknis secara optimal ataupun berupa tindakan-tindakan lain yang disesuaikan dengan sifat perubahan dari lingkungna organisasi / perusahaan. Tindakan restrukturisasi selain mengacu kepada sarana-sarana vital dengan apa organisasi / perusahaan mencapai rasionalisasi, juga dibarengi dengan upaya-upaya berupa; penetapan batasan tanggung jawab, alokasi penggunaan sumber daya - sumber daya dan faktor-faktor lain, modifikasi-modifikasi yang perlu dilakukan baik terhadap karakteristik organisasi / perusahaan, karakteristik kerja maupun karakteristik individu.

Dalam suatu organisasi / perusahaan terdapat variabel-variabel determinan produktivitas yang dapat dimodifikasi dan dikembangkan untuk menciptakan kultur kerja produktif. Variabel- ariabel determinan produktivitas dalam organisasi / perusahaan tersebut adalah: 
1. Lingkungan

Kondisi lingkungan yang bersifat eksternal merupakan salah satu variabel penentu produktivitas dalam organisasi/perusahaan.

2. Karakteristik organisasi/perusahaan

Banyak bukti-bukti menunjukan bahwa secara logis praktek-praktek organisasi/perusahaan yang mempengaruhi individu-individu, pola tingkah laku kerja, pelaksanaan tugas dan efektivitas organisasi/perusahaan tidak selalu mempunyai efek yang sama.

3. Karakteristik kerja

Faktor - faktor lain yang sebagian besar dapat dikendalikan oleh manajemen dan dapat mempengaruhi produktivitas dalam organisasi/perusahaan adalah tugas.

4. Karakteristik individu

Pelaksanaan tugas yang relevan dengan karakteristik individu diekspresikan sebagai suatu fungsi perkalian dari variabel motivasi dan kemampuan.

\subsection{Proyek Konstruksi}

Proyek konstruksi adalah suatu rangkaian kegiatan / aktifitas yang hanya satu kali dilaksanakan dan umumnya berjangka pendek. Proyek menggunakan sumber-sumber (input), misalnya uang dan tenaga kerja, untuk mendapatkan manfaat atau hasil pada masa yang akan datang. Aktivitas Proyek ini mepunyai saat mulai (starting point) dan saat berakhir (ending point). Jadi suatu proyek merupakan: rangkaian aktivitas, penggunaan input, suatu aktivitas yang ada manfaatnya di masa yang akan datang, ada saat mulai dan saat berakhir (Pudjosumarto, 1995).

\section{A. Karakteristik Dalam Proyek Konstruksi.}

Proyek konstruksi mempunyai tiga karakteristik yang dapat dipandang secara tiga dimensi. Yaitu: Bersifat Unik, Dibutuhkan Sumber Daya (Resources) dan Organisasi.

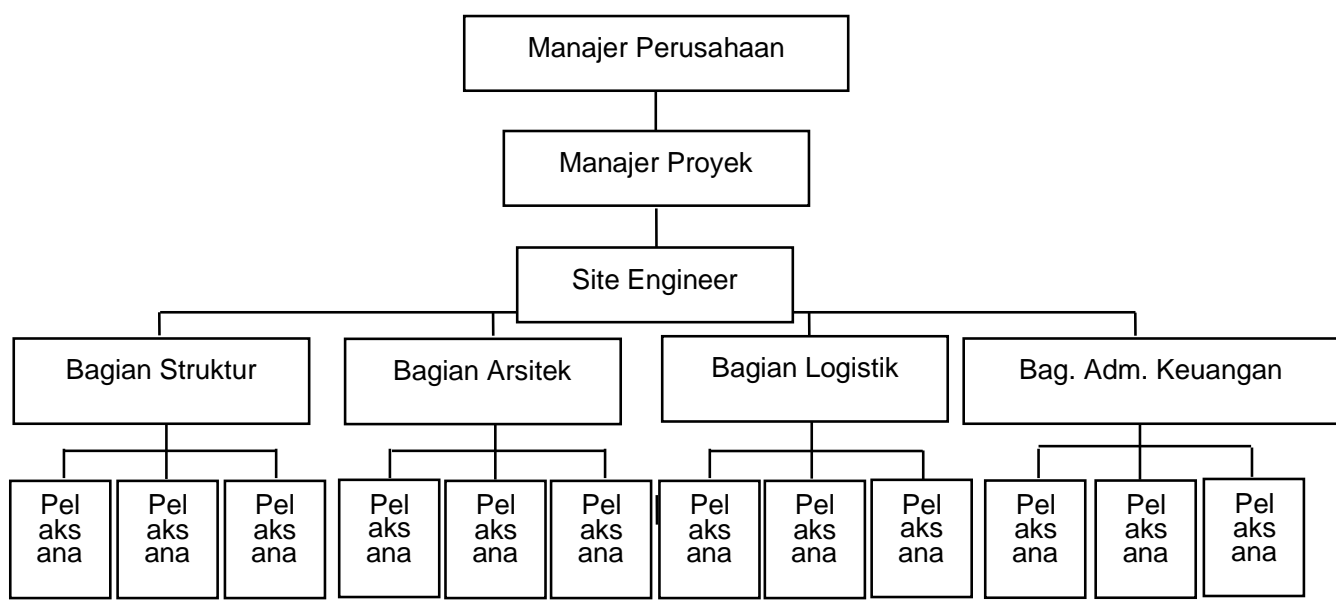

Diagram 1 Struktur Organisasi Pelaksana Proyek

\section{B. Pihak-Pihak Yang Terlibat Dalam Proyek Konstruksi}

Hubungan antara pihak-pihak yang terlibat dalam suatu proyek umumnya di bedakan menjadi dua, yaitu hubungan fungsional dan hubungan kerja (formal). Hubungan fungsional, yaitu pola hubungan yang berkaitan dengan 
fungsi pihak-pihak tersebut, secara fungsional ada tiga pihak yang sangat berperan dalam suatu proyek konstruksi, yaitu: pemilik proyek, konsultan, dan kontraktor; sedangkan hubungan kerja (formal), yaitu pola hubungan yang berkaitan dengan kerjasama antara pihak-pihak yang terlibat dalam proyek konstruksi yang dikukuhkan dengan suatu dokumen kontrak. Secara skematik, pihak-pihak terkait dalam suatu proyek konstruksi dapat digambarkan.

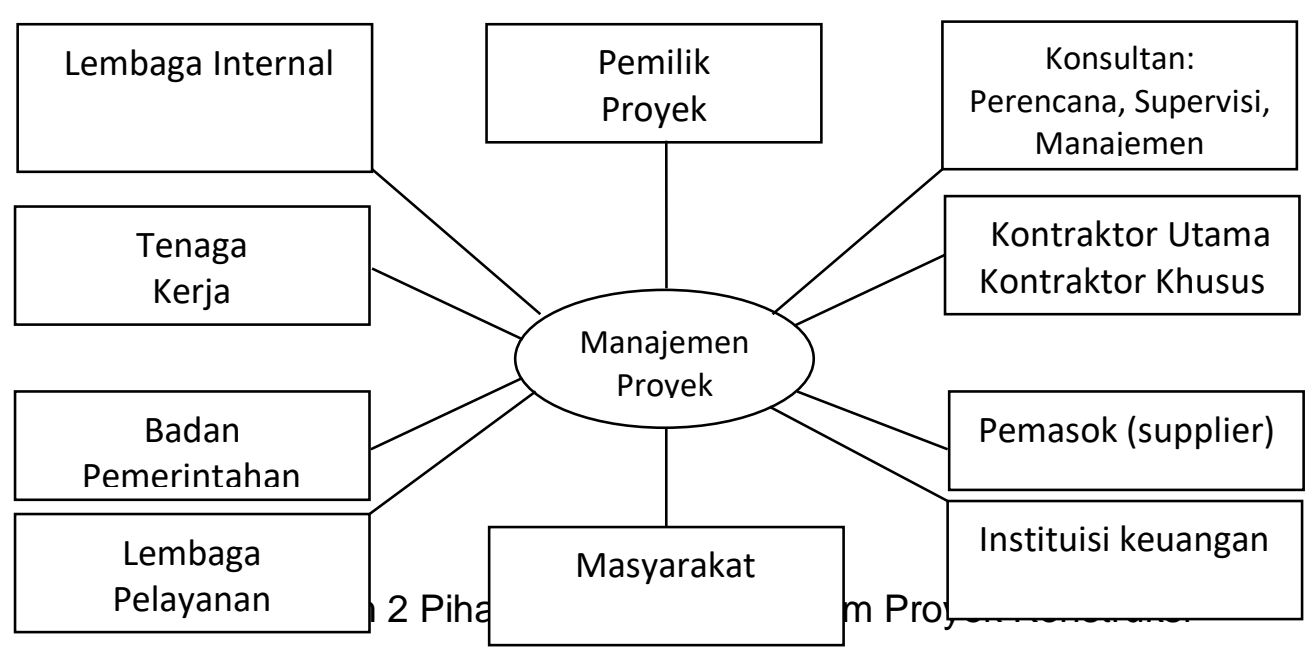

\section{METODA PENELITIAN}

Penelitian meliputi studi literatur, pengambilan data, penyebaran kuesioner, pengambilan kuesioner, rekapitulasi dan penyiapan data, analisis dan pembahasan.

Jenis penelitian ini adalah non-eksperimental dan bersifat lapangan. Lokasi penelitian dilakukan di PT. Pembangunan Perumahan (Persero), PT. Wahyu Prima, PT. Perwita Karya dan PT. Margahayu Rejo. Dalam penelitian ini menggunakan analisis statistik korelasi, anatara lain :

1. Populasi

Populasi dalam penelitian ini adalah pemimpin pada proyek konstruksi Daerah Istimewa Yogyakarta.

2. Sampel dan Teknik Pengambilan Sampel

Kesimpulan dari sampel akan diberlakukan untuk populasi. Karena populasinya besar maka penulis mengambil sampel sebanyak 4 perusahaan besar. Teknik pengambilan sampel dalam penelitian ini penulis menggunakan simple random sampling (sampel acak sederhana). Metode ini dilakukan secara simpel untuk menghindari keberpihakan terhadap obyek penelitian, sehingga dapat menghasilkan keputusan yang obyektif.

3. Data Primer.

Data primer adalah kuesioner yang diisi oleh responden.

4. Data Sekunder

Data sekunder adalah data dalam penelitian yang diperoleh dari Badan Sertifikasi Asosiasi Gabungan Pelaksana Konstruksi Nasional Indonesia (GAPENSI) DIY. 
Alat ukur yang digunakan dalam penelitian ini adalah kuesioner tertutup yang disusun secara terstruktur yang berisi pertanyaan yang harus diisi responden.

Pengukuran instrumen di dalam angket tersebut terdapat 28 item pertanyaan yang masing-masing terdiri dari 5 alternatif jawaban yang mempunyai kualitas yang berurutan dari 5, 4, 3, 2 hingga 1. Untuk lebih jelasnya dapat dilihat dari tabel berikut ini.

Tabel 1. Nilai Tiap Item Soal

\begin{tabular}{|c|c|c|}
\hline No. & Alternatif Jawaban & Nilai \\
\hline 1. & STS & 1 \\
\hline 2. & TS & 2 \\
\hline 3. & N & 3 \\
\hline 4. & S & 4 \\
\hline 5. & SS & 5 \\
\hline
\end{tabular}

Dari Tabel 1 mengenai pengukuran nilai dari tiap item soal tersebut, maka selanjutnya penulis menyajikan skor huruf dari tiap responden sehingga akan diperoleh skor angka (nilai kuantitatif) untuk masing-masing responden

1. Karakteristik pemimpin

Guna mengukur karakteristik pemimpin (Variabel X), maka digunakan instrumen sub variabel (indikator pertanyaan) penelitian. Sedangkan pengukuran indikator menggunakan Skala Likert (Simamora, 2004: 147) dengan skor 5 (jika menjawab sangat setuju), 4 (jika menjawab setuju), 3 (jika menjawab netral), 2 (jika menjawab tidak setuju) dan 1 (jika menjawab sangat tidak setuju). Skala Likert digunakan untuk mengukur karakteristik yang mendasarkan pada rata-rata jawaban. Setelah pernyataan dibagikan maka responden yang diteliti diminta untuk menunjukan intensitas persetujuan terhadap pertanyaan yang ada dalam kuesioner.

2. Produktivitas kerja

Guna mengukur produktivitas kerja (Variabel Y), maka digunakan instrumen sub variabel (indikator pernyatan) penelitian. Sedangkan pengukuran indikator menggunakan Skala Likert (Simamora, 2004: 147) dengan skor 5 (jika menjawab sangat setuju), 4 (jika menjawab setuju), 3 (jika menjawab netral), 2 (jika menjawab tidak setuju) dan 1 (jika menjawab sangat tidak setuju). Skala Likert digunakan untuk mengukur produktivitas kerja yang mendasarkan pada rata-rata jawaban. Setelah pernyataan dibagikan maka responden yang diteliti diminta untuk menunjukan intensitas persetujuan terhadap pertanyaan yang ada dalam kuesioner.

Untuk menjawab rumusan masalah digunakan analisis korelasi Pearson Product Moment dengan rumus sebagai berikut:

(Sugiyono, 2006: 213)

$$
r_{x y}=\frac{\sum x y}{\sqrt{\left(\Sigma x^{2} y^{2}\right)}}
$$

Keterangan:

$r_{x y}$ : Korelasi antara $X$ (karakteristik pemimpin) dan $\mathrm{Y}$ (produktivitas kerja) 
$\sum_{x y}:$ Jumlah $\mathrm{x}$ dan $\mathrm{y}$

$\mathrm{x}$ : Variabel karakteristik pemimpin

y : Variabel produktivitas perusahaan jasa konstruksi

Untuk mengetahui ada atau tidaknya hubungan antara karakteristik pemimpin dengan produktivitas kerja pada proyek konstruksi bisa diketahui dengan:

$\mathrm{Ha}: \rho=0$ (jika tidak terdapat hubungan antara variabel $\mathrm{X}$ dan variabel $\mathrm{Y}$ )

Ho : $\rho \neq 0$ (jika terdapat hubungan antara variabel $X$ dan variabel $Y$ )

Selain menggunakan rumus Pearson Product Moment secara manual, penulis juga menggunakan aplikasi SPSS 12.0 untuk menghitung secara tepat dan cepat mengenai hubungan antara karakteristik pemimpin dengan produktivitas kerja pada proyek konstruksi.

\section{HASIL PENELITIAN}

\subsection{Deskripsi Responden}

Deskripsi responden dijelaskan berdasarkan: jabatan, usia, jenis kelamin, tingkat pendidikan dan lama jabatan. Deskripsi tersebut diperoleh dari responden yang mengisi kuesioner.

\subsection{Analisis Karakteristik Pemimpin Pada Proyek Konstruksi}

Cara yang digunakan untuk menganalisis berbagai karakter yang dimiliki tiap-karakteristik ialah dengan melakukan kategorisasi dari berbagai karakter itu berdasarkan:

\section{A. Persepsi seorang staf tentang peranan pimpinan pada proyek konstruksi.}

Presepsi staf tentang peranan pimpinan dalam penelitian ini meliputi:

1. Pengambilan keputusan.

Karakteristik pemimpin pada proyek konstruksi di Daerah Istimewa Yogyakarta dalam mengambil keputusan berdasarkan keinginannya sendiri, dilakukan dengan cepat, tepat dan cermat.

2. Pengaturan manajerial.

Karakteristik pemimpin pada proyek konstruksi di Daerah Istimewa Yogyakarta mengatur manajerial pada perusahaannya.

3. Pemberian perintah.

Karakteristik pemimpin pada proyek konstruksi di Daerah Istimewa Yogyakarta memberikan perintah kepada staf serta memberitahukan apa yang harus dikerjakannya.

4. Penegakan disiplin kerja

Karakteristik pemimpin pada proyek konstruksi di Daerah Istimewa Yogyakarta menegakan disiplin kerja yang tinggi.

\section{B. Nilai-nilai yang dianut}

Nilai-nilai yang dianut dalam penelitian ini meliputi:

1. Penetapan sasaran perusahaan yang di anut pemimpin.

Karakteristik pemimpin pada proyek konstruksi di Daerah Istimewa Yogyakarta menetapkan sasaran berdasarkan tujuan perusahaan.

2. Tindakan untuk mempermudah tercapainya tujuan.

Karakteristik pemimpin pada proyek konstruksi di Daerah Istimewa Yogyakarta melakukan tindakan yang dinilai benar untuk mempermudah tercapainya tujuan.

3. Pemberlakuan peraturan. 
Karakteristik pemimpin pada proyek konstruksi di Daerah Istimewa Yogyakarta melakukan pemberlakuan peraturan.

4. Pengendalian prilaku dan situasi.

Karakteristik pemimpin pada proyek konstruksi di Daerah Istimewa Yogyakarta melakukan pengendalian prilaku dan situasi dalam perusahaannya.

C. Sikap dalam mengemudikan jalannya perusahaan/organisasi.

Sikap dalam mengemudikan jalannya perusahaan dalam penelitian ini meliputi:

1. Sifat sabar dalam diri pemimpin.

Karakteristik pemimpin pada proyek konstruksi di Daerah Istimewa Yogyakarta memiliki sifat sabar dalam dirinya.

2. Ketenangan ketika dihadapkan dengan sesuatu.

Karakteristik pemimpin pada proyek konstruksi di Daerah Istimewa Yogyakarta ketika dihadapkan dengan sesuatu akan berusaha untuk selalu tenang.

3. Penekanan proyek/birokrasi administrsi.

Karakteristik pemimpin pada proyek konstruksi di Daerah Istimewa Yogyakarta lebih menekankan proyek/birokrasi administrasi tetapi sedikit perhatian terhadap bawahan/stafnya.

4. Komitmen pemimpin pada proyek konstruksi.

Karakteristik pemimpin pada proyek konstruksi di Daerah Istimewa Yogyakarta memiliki komitmen tinggi terhadap sasaran perusahaannya.

\subsection{Analisis Produktivitas Kerja Perusahan}

Untuk mencapai hasil akhir yang cukup baik, dalam proses produktivitas ini mengacu kepada petunjuk-petunjuk umum seperti memasukan indikator-indikator sasaran yaitu:

A. Pola Tingkah Laku Kerja

Pola tingkah laku kerja dalam penelitian ini meliputi:

1. Ketepatan waktu dalam bekerja.

Produktivitas kerja pada proyek konstruksi di Daerah Istimewa Yogyakarta memiliki tingkah laku tepat waktu dalam bekerja.

2. Penilaian hasil kerja staf.

Produktivitas kerja pada proyek konstruksi di Daerah Istimewa Yogyakarta dalam penilaian staf/bawahan ada yang menilai atas dasar laporan bulanan dan tidak mengetahui penilain hasil kerjanya.

3. Program pelatihan dan pengembangan

Produktivitas kerja pada proyek konstruksi di Daerah Istimewa Yogyakarta memiliki tingkah laku pemberian pelatihan dan pengembangan terhadap stafnya.

4. Prosedur pencapaian tujuan perusahaan/organisasi.

Produktivitas kerja proyek konstruksi di Daerah Istimewa Yogyakarta di lakukan dengan menggunakan berbagai prosedur dalam mencapai tujuannya.

\section{B. Pelaksanaan Tugas}

Pelaksanaan tugas dalam penelitian ini meliputi:

1. Pencarian dana/proyek

Produktivitas kerja proyek konstruksi di Daerah Istimewa Yogyakarta dalam pencarian proyek dilaksanakan oleh pemimpinnya.

2. Penyelesaian pelaksanakan pekerjaan perusahan

Produktivitas kerja proyek konstruksi di Daerah Istimewa Yogyakarta menyelesaikan pelaksanaan pekerjaannya diselesaikan dengan tepat waktu sesuai kontrak.

3. Bonus akhir tahun. 
Perusahaan jasa konstruksi di Daerah Istimewa Yogyakarta dalam meningkatkan produktivitas kerja memberikan bonus akhir tahun.

4. Kesesuaian setiap pelaksanaan pekerjaan proyek.

Perusahaan jasa konstruksi di Daerah Istimewa Yogyakarta setiap pelaksanaan pekerjaan proyeknya disesuaikan dengan ketetapan dalam kontrak.

C. Efektivitas perusahaan / organisasi

Efektivitas perusahaan dalam penelitian ini meliputi:

1. Pembuatan laporan.

Perusahaan jasa konstruksi di Daerah Istimewa Yogyakarta melakukan efektifitas pembuatan laporan.

2. Melakukan evaluasi.

Perusahaan jasa konstruksi di Daerah Istimewa Yogyakarta melakukan evaluasi rugi laba.

3. Perubah struktur perusahaan/organisasi.

Perusahaan jasa konstruksi di Daerah Istimewa Yogyakarta akan melakukan perubahan struktur apabila diperlukan untuk meningkatkan produktivitas kerjanya.

4. Koordinasi dalam perusahan.

Perusahaan jasa konstruksi di Daerah Istimewa Yogyakarta melakukan koordinasi untuk meningkatkan produktivitas kerjanya.

D. Efesiensitas kerja

Efesiensitas kerja dalam penelitian ini meliputi:

1. Kesesuaian pekerjaan dengan gaji.

Gaji yang diperoleh belum sesuai dengan pekerjaan yang di kerjakannya, sehingga perusahaan jasa konstruksi di Daerah Istimewa Yogyakarta belum efesien dalam memberikan gaji/upah kepada stafnya.

2. Pertambahan pekerjaan.

Pertambahan pekerjaan tiap tahunnya tidak selau tetap, sehingga perusahaan jasa konstruksi di Daerah Istimewa Yogyakarta efesiensitas kerja dapat meningkatkan produktivitas.

3. Pertambah jumlah staf.

Setiap tahunnya tidak mengalami pertambahan staf sehingga perusahaan jasa konstruksi di Daerah Istimewa Yogyakarta efesiensitas kerjanya dapat meningkatkan produktivitas.

4. Hasil setiap pelaksanaan proyek konstruksi.

Perusahaan jasa konstruksi di Daerah Istimewa Yogyakarta setiap pelaksanaan proyek disesuaikan hasilnya dengan ketetapan kontrak sehingga dapat meningkatkan produktivitas. 


\subsection{Analisis Hubungan Karakteristik Pemimpin Terhadap Produktivitas Kerja Pada Proyek Konstruksi di Daerah Istimewa Yogyakarta.}

Analisis korelasi (hubungan) yang digunakan dalam penelitian ini adalah menggunakan Pearson Product Moment. Dengan menjadikan variabel karakteristik pemimpin sebagai variabel $\mathrm{X}$ dan variabel produktivitas kerja sebagai variabel $\mathrm{Y}$, maka diperoleh hasil sebagai berikut:

\section{Tabel 2. Hubungan Antara Karakteristik Pemimpin Terhadap Produktivitas Kerja Pada Proyek Konstruksi di DIY}

\begin{tabular}{|l|r|r|}
\hline \multicolumn{1}{|c|}{ Pembeda } & Karakteristik Pemimpin & Produktivitas kerja \\
\hline Pearson Correlation & 1 &, $710\left(^{* *}\right)$ \\
Sig. (2-tailed) &. &, 000 \\
N & 20 & 20 \\
Pearson Correlation &, $710\left(^{* *}\right)$ & 1 \\
Sig. (2-tailed) &, 000 &. \\
N & 20 & 20 \\
\hline
\end{tabular}

Data Primer, $2008^{* *}$ Correlation is significant at the 0.01 level (2-tailed).

Berdasarkan tabel tersebut dapat diketahui:

a. Nilai koefisien korelasi antara karakteristik pemimpin dengan produktivitas kerja pada Proyek Konstruksi di DIY sebesar 0,710.

b. Signifikansi 1

c. $\alpha$ sebesar 0,01

d. Hipotesis $\mathrm{H}_{\mathrm{o}}=$ tidak ada hubungan dan $\mathrm{Ha}=$ Ada hubungan. Jika sig. $\rho>\alpha$, maka $\mathrm{H}_{\circ}$ diterima, jika sig. $\rho<\alpha$, maka $\mathrm{H}_{\circ}$ ditolak

Karena sig $\rho(0,000)<$ dari $\alpha$ sebesar 0,01 , maka dapat disimpulkan bahwa ada hubungan antara karakteristik pemimpin tehadap produktivitas kerja pada proyek konstruksi di daerah istimewa Yogyakarta. Dengan hasil analisis tersebut karakteristik pemimpin sangat berhubungan kuat terhadap produktivitas kerjanya.

\section{KESIMPULAN DAN SARAN}

\subsection{Kesimpulan} berikut:

Berdasarkan hasil penelitian yang dilakukan, dapat ditarik kesimpulan sebagai

1. Dari hasil seluruh instrument variabel $x$ yang ada maka diketahui presentase kumulatif: Sangat Tidak Setuju $=0 \%$, Tidak Setuju $=5 \%$, Netral $=19,6 \%$, Setuju $=59,6 \%$ dan Sangat Setuju $=15,8 \%$.

Dengan demikian dapat disimpulkan bahwa nilai karakteristik pemimpin pada proyek konstruksi di daerah istimewa Yogyakarta yang paling dominan adalah sebesar $59,6 \%$ (setuju) atau dengan kata lain memiliki karakteristik otokratik dan birokratik.

2. Dari hasil seluruh instrument yang ada maka diketahui presentase kumulatif: Sangat Tidak Setuju $=0 \%$, Tidak Setuju $=10,3 \%$, Netral $=32,5 \%$, Setuju $=$ $45,6 \%$ dan Sangat Setuju $=11,6 \%$. 
Dengan demikian dapat disimpulkan bahwa nilai dominan dari produktivitas kerja pada proyek konstruksi di daerah istimewa Yogyakarta adalah sebesar 45,6\% (setuju) atau dengan karakteristik pemimpin otokratik dan birokratik dapat meningkatkan produktivitas kerja.

3 . Setelah dilakukan pengujian hipotesis dengan menggunakan uji statistik korelasi Pearson Product Moment, diperoleh sig $\rho(0,000)<\alpha(0,01)$, maka dapat disimpulkan bahwa ada hubungan antara karakteristik pemimpin terhadap produktivitas kerja pada proyek konstruksi di daerah istimewa Yogyakarta. Dengan hasil analisis tersebut karakteristik pemimpin sangat berhubungan kuat terhadap produktivitas kerjanya dengan tingkat signifikan 1.

\subsection{Saran}

1. Bila wewenang pemimpin otokratik menjadi menekan sehingga bawahan merasa takut dan tidak pasti, maka perlu sadar mengenai dirinya, kelompok, dan situasi karena karakteristik pemimpin yang otokratik dapat menjadi otokratik kebapakbapakan apabila hanya memberikan perintah, memberikan pujian dan menuntut loyalitas bahkan dapat membuat bawahan merasa mereka sebenarnya ikut serta dalam membuat keputusan walaupun mereka mengerjakan apa yang dikehendaki pimpinan.

2. Perlu diusahakan agar orang/bawahan mengakui bahwa ada keterkaitan kuat antara kepuasaan bekerja dan pencapian pekerjaan serta perlu lebih diperhatikan dalam melakukan pengukuran produktivitas pada faktor sumber daya manusia.

\section{UCAPAN TERIMA KASIH}

Penulis mengucapkan terima kasih yang tulus kepada Bapak Ir. Ilham Poernomo, MT (Praktisi dan Akademisi) dan saudara Holil mahasiswa Jurusan Teknik Sipil Universitas Cokroaminoto Yogyakarta yang telah banyak membantu dalam penelitian ini.

\section{DAFTAR PUSTAKA}

A Dale Timpe, 2002, Seri Manajemen Sumber Daya Manusia Kepemimpinan, PT. Elex Media Komputindo, Jakarta.

Arikunto, Suharsimi, 1989, Prosedur Penelitian: Suatu Pendekatan Praktis, Bumi Aksara, Jakarta

Drs. Muchdarsyah Sinungan, 1995, Produktivitas Apa Dan Bagaimana, Cetakan Kedua, Bumi Aksara, Jakarta.

Kartono Kartini, 1994, Pemimpin Dan Kepemimpinan:Apakah Pemimpin Abnormal Itu?, PT. Raja Grafindo Persada, Jakarta.

Kuncoro, Mudrajad, 2003, Manajemen Untuk Bisnis dan Ekonomi, Erlangga, Jakarta

Mauled Mulyono, S.E., 1993, Penerapan Produktivitas Dalam Organisasi, Bumi Aksara, Jakarta.

Nawawi, 2003, Metode Penelitian Bidang Sosial, Gadjah Mada University Press, Yogyakarta

Prof. Dr. Sondang P. Siagian, 1991, Teori Dan Praktek Kepemimpinan, PT. Rineka Cipta, Jakarta. 
Santoso, Singgih, 2002, Latihan SPSS Statistik Parametrik, Elek Media, Komputindo, Jakarta.

Simamora, Bilson, 2004, Riset Pemasaran: Falsafah, Teori dan Aplikasi, PT. Gramedia Pustaka Utama, Jakarta

Sugiyono, 2006, Statistika untuk Penelitian, Alfabeta, Bandung

Surachmad, Winarno, 1982, Pengantar Penelitian Ilmiah,Tarsito, Bandung

Wolfram I. Ervianto, 2002, Manajemen Proyek Konstruksi, Andi Offset, Yogyakarta. 